
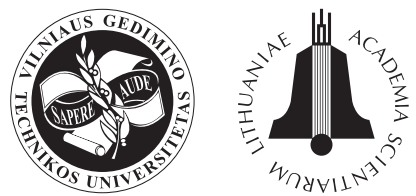

TRANSPORT

2010

25(2): $203-214$

\title{
THE EVALUATION OF INVESTMENT PROJECTS WITHIN THE TERRITORY OF DEVELOPMENT
}

\author{
Aušrinè Griškevičiūtè-Gečienè \\ Dept of Urban Engineering, Vilnius Gediminas Technical University, \\ Sauletekio al. 11, LT-10223 Vilnius, Lithuania \\ E-mail: ausrine.griskeviciute@vgtu.lt
}

Received 20 December 2009; accepted 20 May 2010

\begin{abstract}
Sustainable development is the most researchable sphere of many experts in urbanistics, architecture, transport, environment and economics in Lithuania. Every period of time has specific problems and solutions to solve them. The present days have increased the level of automobilization and growing traffic in cities has become the main task for sustainable development. State-wide improvement and development of transport infrastructure relate to the level of assigned investments that depend on State transport policy and existing opportunities. Comparing to several EU member states, the procedures of evaluating data on transport infrastructure projects evolved in parallel with the EU-financed projects. Therefore, it could be stated that this area is not falling behind.The analysis of evaluation methods in Lithuania and foreign countries showed that there were no standardized and united methods for evaluating projects on urban system infrastructure. During the last decade, investment projects in cooperation with the State were evaluated using complex analysis in Lithuania. Cost-benefit analysis was and is still being used for evaluating the EU-financed projects. Multicriteria analysis is often carried out in the EU and other countries to evaluate the financial feasibility of transport infrastructure and takes its first steps in Lithuania.
\end{abstract}

Keywords: sustainable development, transport system infrastructure, socio-economic evaluation, cost-benefit analysis, multi-criteria analysis, social costs, negative transport impacts.

\section{Introduction}

Sustainable development is one of the main areas investigated by a number of Lithuanian and foreign scientists including urbanists, architects, experts in the field of transport, environment, economic and other branches of sciences (Ruiz et al. 2004; Oppen and Løkketangen 2006; Tanczos and Torok 2007; Ziari et al. 2007; Brauers et al. 2008; Daunoras et al. 2008; Figliozzi 2008; Niewczas et al. 2008; Vega and Penne 2008; Antov et al. 2009; Burinskienè 2009; Burinskienè and Rudzkiené 2009; Çalışkanelli et al. 2009; Janáček and Gábrišová 2009; Li et al. 2009; McDonald et al. 2009; Mesarec and Lep 2009; Szücs 2009; Matis 2008, 2010). In a broad sense, the object of sustainable development can be determined both a sustainable city or region or even a country. Many authors (Burinskienė and Rudzkienè 2006; Juškevičius and Burinskienè 2007; Moss and Fichter 2003; Guy and Kibert 1998) determine sustainable development as an endeavour to harmonize city growth with social progress reducing the waste of non-renewable natural resources and negative impacts on ecological balance. The cohesion of economic, social and ecologic aspects composes the base of sustainable city development.
Every period of time can be characterized with specific transport problems, their conception and the choice of solutions. According to urbanists (Burinskienè and Rudzkienè 2006; Juškevičius and Burinskienè 2007), the period of the last 20-30 years can be described as one facing the problem of communication systems of Lithuanian cities which overgrew usual transport problems and became a large component of environmental, social and psychological stresses in cities. The main reasons for the encountered situation are private cars and less - other types of vehicles.

An increase in the level of automobilization, growing transport flows in urban territories and decreasing investment for the development of transport infrastructure are the main barriers for urban development. An uncontrolled increase in automobilization usually proceeds till the Government is able to develop technical infrastructure guaranteeing a sufficient quality of the transport system. On the other hand, a lack of investment for the reconstruction or development of infrastructure leads to an increase in negative impacts on society and environment.

A technical attitude to plan investment in the infrastructure of transport systems guided by common nor- 
mative documents dominated during the soviet period. Economic evaluations were not prepared as engineering practice was used. In the first decade after the recovery of the Independence of the Republic of Lithuania, investment projects started to be prepared seeking to receive support from the financial institutions of foreign countries. But still, a lack of knowledge, practice and legislation to prepare the projects corresponding international requirements was felt. Technical support was provided by the experts of Western Europe. After EU accession, financial support for the transport sector has been rendered from the EU Structural and Cohesion funds. Structural policy funds are seeking to help regions having thin time adapt to changing economical and social circumstances (Single Programming Document ... 2004).

The aim of this paper is to determine the main transport problems in the urban territories of Lithuania, to analyze principal methods for the evaluation of investment projects and to compare our practice with that applied in foreign countries.

\section{Overview of Transport Problems in Lithuanian Cities}

Data on transport statistics in Lithuania shows that within the period of recent six years solely the car ownership level has increased by 1.36 times. However, the Lithuanian city street network and other infrastructure fall much behind the rapidly growing number of cars and their flows in streets - the parameters of streets in a number of Lithuanian largest cities do not meet technical categories required by normative documents. Statistics shows that traffic congestions in the main connecting city streets and arteries having connection to rural roads have increased and make a negative effect on economy, social sphere, health and urban environment. If the system worked smooth, people and cargoes would not be late and a negative effect on them would be decreased. Therefore, the main objective of local authorities is to reduce a negative effect of congestions and to assure the economic welfare of the cities (Griškevičius and Griškevičienè 2004, 2007; Odgaard et al. 2005). In consideration of the existing situation, the following main groups of problems caused by the increased level of vehicle ownership can be distinguished:

- In economic terms, the main negative outcome of the increased level of vehicle ownership and traffic congestions is wasting travel time. The experts suppose that (Caulfield and O'Mahony 2007; Eliasson 2006; Kinderytė-Poškienè and Sokolovskij 2008), namely time saving is the essential criterion showing the level of transport infrastructure development. In economy, travel time is expressed in monetary terms and from the point of view of a person, delayed time creates costs since at that time $\mathrm{s} / \mathrm{he}$ is not able to make any other activity. Investigations of foreign specialists showed that due to increasing traffic flows in city centres the everlasting congestions occurred all over Europe in the result of which
European economy loses almost 100 billion EUR per year, i. e. $1 \%$ of EU GDP.

- In terms of traffic safety the increased level of car ownership as well as traffic congestions are the major reasons for the increased number of accidents in cities. From the beginning, traffic safety was one of the main tasks of EU transport policy. Based on the EU statistical data, in 2005, nearly 42 thousand people were killed on the roads of the EU member states. Due to expected danger to personal safety, certain social groups sometimes refuse travelling or using services of public transport. This, in turn, can become a reason for refusing not only public transport infrastructure but also private cars (Kinderytè-Poškienè and Sokolovskij 2008; Bruinsma et al. 2001; Cantos et al. 2005; Communication from the Commission ... 2008).

- In terms of territorial planning, the increased level of car ownership affects the use of the existing urbanized territories for parking. The experts give an opinion (Bruinsma et al. 2001; Bulkeley and Rayner 2003; Herala 2003; Yuen and Chor 1998; Communication from the Commission ... 2008) that parking is one of the most difficult problems of city transport because it requires space which, in view of the increased number of passenger cars, is a considerable use of urbanised territories taking into account that the city land must be used economically. Experience of the last decade shows that parking in the main streets is one of the measures to reduce and abate traffic in a certain territory of the city, especially where there is large concentration of attraction objects, together with the use of parking-time restriction measures, differentiation of vehicle types according to time, etc. A different situation could be found within the limits of residential districts where the problem of parking cars in the yards is rather difficult to be solved due to a lower amount of cars predicted in the Soviet construction standards resulting in a lower amount of parking places. Here, over ground and underground garages come to help and are successfully used as a measure to reduce housing of urbanized territories and to decrease the use of passenger cars.

- The use of urbanized territories is interconnected with the problem of rural transit through the territory of the city. The current situation shows that distant by-passes are not effective, poorly paid back and rural traffic is further using old routes through the trafficked streets. Therefore, creating an integrated network of high-speed streets and rural motorways would give a long-term favourable effect for the transformation of urban infrastructure. In recent years, with the financial support from the EU funds, Lithuania implements the construction of close by-passes in cities. In this case, the main high-speed streets serve as a 
by-pass where the single-sided development of the route is tolerated or the route is built in a free area of the built-up territory as a scaffold bridge or in a tunnel. One of the most striking examples is Vilnius City Southern by-pass (Burinskienè and Ušpalyté-Vitkūnienè 2008; Juškevičius and Burinskienè 2007; Lithunian Road Administration ... 2002).

- The increased level of car ownership and uneven infrastructure development are the main reasons for the decreased attractiveness of public transport during the last decade. An increase in services and in the development priority of public transport within the total transport flow is one of the basic trends of urban modernization anticipated in EU transport policy. A measure emphasized in the EU White Paper is to transfer public spaces used by passenger cars to public transport. The network of public transport should cover the urban territory in a way to guarantee the network access on foot. One of the ways to achieve this purpose is to modernize the existing transport infrastructure. The largest changes were implemented in Vilnius City. By giving a priority lane to buses and trolley-buses and a priority to public transport to cross intersections, the quality of public transport would be increased along with the expectation that inhabitants would be using public transport more and more frequently. Unfortunately, the environment in the majority of large Lithuanian cities is not economical and rational with regard to passenger transportation (Burinskienè and Ušpalytė-Vitkūnienė 2008; Bulkeley and Rayner 2003).

- In terms of environmental protection, road traffic is one of the main causes for a poor quality of city environment. The experts (Yuen and Chor 1998; Herala 2003; Pearce et al. 2006; Caulfield and O'Mahony 2007; Cantos et al. 2005; Communication from the Commission... 2008) agree that an environmental impact caused by the transport sector has been increasing more constantly than any other sector of national economy. This is especially relevant to urban transport. If compared to other transport modes, road transport is the most intensive user of land and takes almost $93 \%$ of the whole territory of the EU, whereas railway infrastructure takes only $4 \%$ of land and air ports - less than $1 \%$. Transport is one of those areas where the problem of $\mathrm{CO}_{2}$ is solved in the most difficult way. Though vehicles became technically improved, however, due to the increasing traffic volume and frequent stopping of vehicle flow in the city streets, $\mathrm{CO}_{2}$ emissions constantly increase and contribute to climate change.

- Various methods, technologies and measures for solving traffic safety and environmental problems caused by increased traffic are suggested giving priority to public transport services, using bio transport, walking, technically planning pedestrian streets (zones) and bicycle paths, narrowing the carriageway of city streets, erecting signalized pedestrian crossings, introducing speed-reduction measures, using Stop signs at intersections, installing traffic lights at intersections, public transport lanes and bus-stops, using intelligent traffic signs, traffic restriction in certain city areas, selecting sites for vehicle stopping and parking, time restrictions, etc.

\section{Evaluation of Investment Projects on Urban transport Systems in Foreign Countries}

The development of and improvements in the level of transport systems on a national scale is inseparable from the level of allocated investments depending on a national policy towards the modernization and development of the transport sector and available possibilities. Having determined the problems of the sector, having formulated the trends and objectives for the development of the whole transport sector and different transport modes, the concrete projects of transport infrastructure are evaluated one by one. The aim of this evaluation is to determine the input of each project to achieve the planned objectives of the sector (Griškevičius and Griškevičienè 2004, 2007; Noya and Clarence 2007; Rus 2006).

This paper gives the analysis of methods for the evaluation of transport infrastructure projects in foreign countries. Table 1 gives a summary of methods used for the evaluation of investment projects on transport infrastructure in the EU countries.

Table 1 shows that CBA is used in most EU countries. CBA is most commonly used for evaluating the eligibility of transport investment projects and programs. This analysis compares the total benefit of a certain project or program to the society with the full costs of its implementation. The main objective is to evaluate if benefit after project implementation exceeds the costs related to project implementation. In this case, the term 'benefit' means everything what increases advantages of a certain project or program and the term 'costs' indicates everything that decreases them.

Table 1. The evaluation methods of investment projects on communication infrastructure in the EU countries

\begin{tabular}{ccc}
\hline $\begin{array}{c}\text { Only Cost-Benefit } \\
\text { Analysis (CBA) }\end{array}$ & Mostly CBA & $\begin{array}{c}\text { Mostly Multi-criteria } \\
\text { Analysis (MCA) }\end{array}$ \\
\hline Denmark & Germany & France \\
\hline Greece & Italy & Belgium \\
\hline Ireland & Great Britain & The Netherlands \\
\hline Portugal & & Austria \\
\hline Spain & & \\
\hline $\begin{array}{c}\text { Other EU } \\
\text { countries }\end{array}$ & & \\
\hline
\end{tabular}


In the countries where MCA is regularly used, CBA is included into a general evaluation. In the EU countries (except Luxembourg), CBA is applied for evaluating the infrastructure of at least one transport mode, mostly in road and railway sectors. CBA is used with a quantitative and (or) qualitative evaluation including those criteria which, due to technical or political reasons, were not included at the earlier stage.

There are three main differences between CBA and MCA. CBA is fully concentrated on economic efficiency, whereas MCA is not restricted to one criteria and its scale of value can include social and other indices. In CBA, all effects are expressed in quantitative terms and valuated, whereas MCA comprises three different groups of evaluation indices: qualitative indices, quantitative indices and a group of mixed criteria (Macharis et al. 2009; Bekefi et al. 2003; Rich and Nielsen 2002).

Table 2 gives the main impacts and their criteria of CBA used for the evaluation of transport infrastructure in the EU countries.

Table 2.The main effects and elements of CBA used in the evaluation of communication infrastructure in the EU countries

\begin{tabular}{ll}
\hline \multicolumn{1}{c}{$\begin{array}{c}\text { Groups of main } \\
\text { effects }\end{array}$} & \multicolumn{1}{c}{ Elements } \\
\hline $\begin{array}{l}\text { Infrastructure } \\
\text { costs }\end{array}$ & $\begin{array}{l}\text { Construction costs } \\
\text { Costs for object maintenance operation, } \\
\text { repair and administration }\end{array}$ \\
\hline User benefits & $\begin{array}{l}\text { Passenger transport time saving, } \\
\text { Vehicle operating costs } \\
\text { Benefit to goods traffic }\end{array}$ \\
\hline Externalities & $\begin{array}{l}\text { Traffic safety, noise, pollution - local/ } \\
\text { regional attitudes } \\
\text { Climate change }\end{array}$ \\
\hline Other & $\begin{array}{l}\text { User charges and revenues } \\
\text { Disruption from construction }\end{array}$ \\
\hline
\end{tabular}

As CBA refers to universal economic calculations, the economic estimates of transport infrastructure projects are calculated by common formulas. Next, several formulas of economic estimates are presented (Guide to Cost-Benefit ... 2008; Golub and Tomasik 2008):

- Economic Net Present Value (ENPV) shows the absolute effect of the project considering time series over the whole existence period of the project:

$$
N=\sum_{t=1}^{k} \frac{G_{t}}{(1+r)^{t}},
$$

where: $N$ - the ENPV of the project; $t$ - cash flow time; $G_{t}-$ the net cash flow of the project at time $t ; r$-discount rate; $k$ - the existence period of the project.
- Economic Internal Rate of Return (EIRR) is discount rate $r$ ' that produces a zero value for the ENPV:

$$
I R R=r^{\prime}, \text { when } N=f\left(r^{\prime}\right)=0,
$$

where: IRR - the economic internal rate of return; $N$ - the ENPV of the project.

$-B / C$ ratio - shows the profitability of the project:

$$
B / C=N_{\text {disk }} / I_{\text {disk }}
$$

where: $B / C$ - the ratio between discounted economic benefits and costs; $N_{\text {disk }}$ - discounted benefit; $I_{\text {disk }}$ - discounted costs.

Table 1 shows that MCA is most commonly used in Austria, Belgium, Greece and the Netherlands. Multicriteria analysis is conducted so that the carried out evaluation of benefits and costs should include not only such factor as money but also other measuring units should be used. Since the applied criteria cannot be directly unified, each index gets corresponding weight and importance. The application of MCA to the transport sector is possible in a very wide aspect and cover political measures, strategic decisions on the evaluation of public transport and the implementation of infrastructure projects. Methods, concepts and approaches make a rather wide spectrum starting with the method of the analytical hierarchy process (Nystrom and Soderholm 2010; Ojha et al. 2010; Bhagwat and Sharma 2009; Bello-Dambatta et al. 2009; Podvezko 2009) (American school and European school) and concluding with Electre (Ghionea 2009; Ulubeyli and Kazaz 2009), Promethee methods (Brans and Vincke 1985; Podvezko and Podviezko 2009, 2010) (European school).

For the evaluation of transport infrastructure, Great Britain started using a New Approach to Appraisal (NATA) that embraces several new criteria that were not included into the standard cost and benefit analysis (Odgaard et al. 2005; Macharis et al. 2009).

In Hungary, the InnoFinance model (Bekefi et al. 2003) was introduced to evaluate transport infrastructure projects. The model is intended for the evaluation of the financial feasibility of the project based on financial criteria for all the years of project lifetime. It enables to make a detail calculation of cash flows taking into consideration all necessary project implementation costs, insurance revenue, cost savings, project implementation and supervision costs. The model analyzes minimal financial demands for cash refund, eligible sources, financial terms (time of pay-back, interest rate, taxes, period of terms, payment of deposits, etc.).

In some European countries, the multi-actor multicriteria analysis (MAMCA) method is used (Macharis et al. 2009) and is specifically focused on the inclusion of qualitative as well as quantitative criteria with their relative importance defined by multiple stakeholders into one comprehensive evaluation process in order to facilitate the decision making process by different stakeholders.

Some authors suggest using CBA and MCA together (Rich and Nielsen 2002; Pearce et al. 2006). For eval- 
uating projects on transport and communication systems, the eclectic MCA method enables to join different analysis measures such as CBA, environmental impact analysis, economy impact analysis, etc.

Japan uses MCA together with CBA without any clear formulation of criteria or determination of priorities (Feng and Wang 2005). CBA involves the evaluation of impacts on regional economy, world-wide and local environment and the ways to minimize those impacts. The scientists of Taiwan created a fully economic method for the evaluation of transport infrastructure projects. In contrast to classical CBA, this new model involves the impacts of various aspects and gives both monetary and non-monetary undefined results. Table 3 gives the example of impacts included into Taiwan model (Feng and Wang 2005).

The USA (Kulkarni et al. 2004) uses an expanded CBA model analyzing the impact of large-scale projects on the capital. Multi-criteria analysis and other methods are mostly used at the level of separate regions. In the evaluation of highway projects, the system of demanddriven priorities is used. The essence of this system is that the projects are selected based on common demand for infrastructure improvement. The projects are divided by their ranks - only the project of a higher rank is selected for financing. A basis for this system is a multicriteria demand function defining the segments of highways, including specific measures called attributes reflecting various objectives of road network maintenance such as the maximisation of safety or users' comfort, decrease in travel delay costs, the maximisation of investment saving, etc. By checking a multi-criteria demand function, the demand functions of different attributes are coordinated as well as the relative weights of different attributes. In case when those evaluations correspond to the multiple objectives of customers, the possibility is checked to ensure the effective work of project stakeholders.

\section{Methodology for the Evaluation of Investment Projects on Urban Transport Systems in Lithuania}

Compared to some EU countries, in Lithuania, procedures for evaluating infrastructure projects on urban transport systems have been developing in parallel with the EU-financed projects, and therefore it could be stated that this area is not falling behind.

Due to a lack of funds, project evaluation is carried out especially thoroughly according to certain methodologies and by justifying their necessity to transport infrastructure and society. There are many investment evaluation methods but not all of them are applicable to transport sector infrastructure. Moreover, there is a problem concerning the evaluation of road and urban infrastructure projects. Theoretically, there must be differences between the methods used for evaluating infrastructure projects on separate road transport (main, national, regional roads and their elements, including bridges, viaducts, crossings, barriers ant etc.) and urban transport systems (streets, city by-passes, pedestrian pavements, bicycle paths and etc.) since road and urban systems infrastructure represents different objects operating under different conditions (territories, users and etc.). Lithuanian practice shows that common methods are used in the evaluation process. Accordingly, the following features characteristic to the whole transport infrastructure investment projects could be singled out (Automobilių kelių investicijų vadovas 2006; Guide to Cost-Benefit... 2008; Griškevičius and Griškevičienè 2004):

- the lifetime (functioning) of the objects is long;

- project implementation requires large funds;

- a construction period of the objects is long;

- operating costs of the objects are relatively small.

Practically, investment projects implemented in cooperation with the State are started to be assessed using multi-criteria evaluation methods. A result of these methods is the evaluation of the efficiency of alternative investment projects according to the selected

Table 3. The example of evaluation effects included in the evaluation of transport infrastructure projects in Taiwan

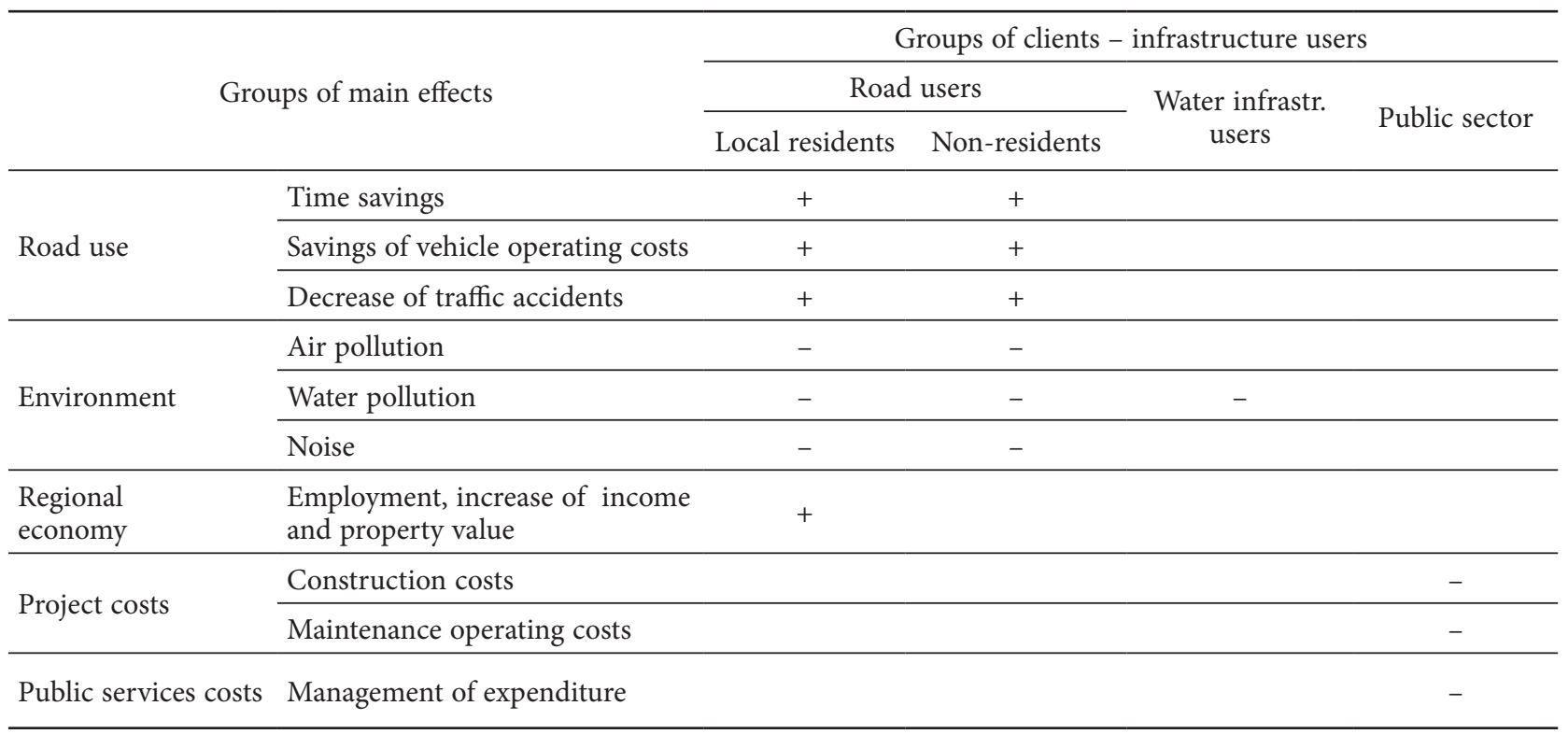


evaluation criteria that shall reflect both the investment project of implementing a subject as well as the interests of the State. The experts suggest using criteria according to economic, social, environmental, ecologic, technical and other aspects used in the methods of former used complex analysis. Figure shows the main suggested steps (Tamošiūnienè et al. 2006; Bivainis and Butkevičius 2003) of evaluating alternative projects using multi-criteria methods.

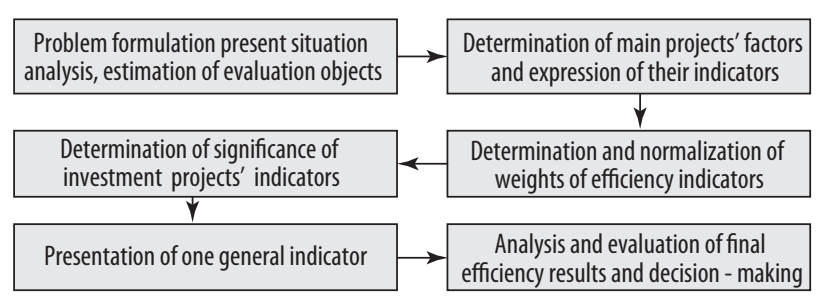

The main steps of evaluation using multi-criteria methods

However, multi-criteria methods are a new approach referring to a quite complicated mathematical basis and requiring the sight of information. Moreover, when evaluating both road and urban transport system infrastructure projects, some factors do not have mathematical quantitative expressions which can be a reason for increasing risk for a wrong interpretation of factors and an uncertain evaluation of projects. Therefore, the legal methodology of evaluating separate investment projects still refers to the classical methods of complex analysis.

Presently, CBA used for the evaluation of projects prepared for getting financial support from the EU funds is a more comprehensive evaluation form than financial analysis since it involves not only financial costs and income but also includes all expenditures and the benefit obtained. This method has a certain level of universal use and helps with evaluating factors having no monetary value. For the evaluation of CBA, social costs are determined which also take part in justifying project efficiency in terms of traffic safety as well as considering technical and financial aspects. Together with CBA results, the earlier described economic values such as Internal Rate of Return, Net Present Value and Benefit/Cost Ratio are determined.

The main 6 steps used in the evaluation of projects for getting financial support from the EU funds are as follows (Automobilių kelių investicijų vadovas 2006; Guide to Cost-Benefit ... 2008; Griškevičius and Griškevičienè 2004, 2007):

- a detailed description of the existing socio-economic situation and determination of project aims;

- a clear description of the object of the project;

- a study on project possibilities and a presentation of possible alternatives;

- financial analysis;

- economic analysis;

- risk evaluation;

- other methods of evaluation (e. g. analysis of cost efficiency, MCA, analysis of economic impacts, etc.).
Besides economic evaluation, social one is used where the effect of investment projects on the public is determined. Besides a distribution of benefits and costs between different groups of population, the evaluation of other character of impacts is carried out. During social justification, external impacts on a number of working places, the use of energy and the introduction of innovative technologies are evaluated. Then, the results of social evaluation are used for evaluating the project taking into account a strategic aspect, i.e. to describe the need for the project, to justify technical solutions and road safety measures, to calculate the number of created jobs (Šarka et al. 2008).

The evaluation of a negative impact of transport on the environment is most commonly related to multi-criteria analysis (Planuojamos ūkinès veiklos... 2009).

The expression of transport-generated negative impact in terms of money is a rather complicated problem as social costs take part in it. Each country has its own methodology, and therefore the evaluation of identical factors differs according to the country. In order to determine the effect of certain factors, complicated and expensive investigations are necessary. Therefore, during the evaluation of investment projects, some factors are evaluated either in physical units or based on their description. In many EU countries, a rather large spectrum of environmental impact criteria is defined (Caulfield and O'Mahony 2007; Odgaard et al. 2005; Pearce et al. 2006). The impact of noise, air pollution and climate change is most commonly assessed considering a local and global aspect. More rarely, depending on the character of the project, the impact of vibration, chemical or physical fragmentation, visual intrusion into territories, decrease of important natural territories, consumption of sources, soil/water pollution, etc. is assessed.

\section{Practice in Evaluating Investment Projects on Urban Transport Systems in Lithuania}

The analysis of the characteristic features of the current assessment system used in the evaluation of investment projects on urban transport system infrastructure was accomplished. The aim of the performed analysis was to define and estimate the main entries of socio-economic aspects and the main effects influencing the implementation of projects. Ten projects prepared for getting financial support from the EU funds according to the requirements of programming stage I (2004-2006) were selected for analysis; six of those were developed by the author. Analysis was based on the already or partly implemented investment projects on urban transport system infrastructure taking into consideration several aspects:

- The selected projects included the modernization of the most different urban transport infrastructure elements (construction or reconstruction) the streets of cities and towns, sidewalks and pedestrian-bicycle paths, traffic safety measures, viaducts, roads in built-up areas, city squares, etc. Special attention was paid to the fact that technical solutions to the projects would meet the laws 
of the Republic of Lithuania as well as the current EU legal acts and would be optimum in terms of traffic safety, in technical, environmental, economic and other aspects.

- The structural analysis of the total cost of projects was carried comparing the estimates. To make evaluation simpler, the projects with the total cost of more than $2.0 \mathrm{mln}$. Lt was selected. analysis.

Table 4 gives the results of the projects selected for

When analyzing the projects selected, the closest attention was paid to social costs used for socio-economic evaluation and their structure on the basis of which impacts could be divided into the following groups:

1. Costs:

- direct costs of planning, designing and implementing the project;

- construction or reconstruction costs of the project;

- maintenance costs of the project;

- costs during construction (reconstruction) works (in certain cases).

2. Benefit:

- savings in the maintenance costs of the existing infrastructure (in certain cases);

- savings in travel time;

- accident savings;

- savings in vehicle operating costs;

- ecological savings - reduction in dustiness (in certain cases)

The analysis of the projects selected showed that the costs of planning, designing and implementing the project included all costs from tender procedures and feasibility studies on investment projects, documents on investment projects and territorial planning and docu-

Table 4. Data on the exemplary projects selected for analysis

\begin{tabular}{lc}
\hline $\begin{array}{l}\text { Title of project/ } \\
\text { Customer }\end{array}$ & Results of project \\
\hline Construction & Accomplished works (2004-2008): \\
of the Missing & - construction of new road (aprx. \\
Link of the IXB & $2.9 \mathrm{~km}$ ); \\
Transport Cor- & - construction of new viaduct for \\
ridor - Vilnius & pedestrian and light vehicles (aprx. \\
southern bypass/ & 0.38 km); \\
Vilnius City & - installation of protective barriers \\
Municipality & (aprx. 5.0 km); \\
& - reconstruction of adjacent transport \\
& infrastructure network (aprx. 4.0 \\
& km); construction of pedestrian pave- \\
& ments and bike paths at the bypass \\
& approaches. \\
\hline Construction & Planned works (2006-2009): \\
and moderniza- & - building of bypass (sequel of \\
tion of the links & Statybininkų street to Išradejų st.; \\
of streets, roads & Išradejju st. between Sembos st. and \\
with bypasses & Daubos st.); \\
and suburbs of & - pavement amplification of Išradejjų st. \\
Šiauliai City (I & between Daubos st. and Pramonès st.; \\
stage)/ Šiauliai & - reconstruction of sequel of Sembos \\
City Municipality & st. between Dariaus ir Gireno st. and \\
& Išradejų st. \\
\hline
\end{tabular}

Continue of Table 4

\begin{tabular}{lc}
\hline $\begin{array}{c}\text { Title of project/ } \\
\text { Customer }\end{array}$ & Results of project \\
\hline The reorganiza- & Accomplished works (2006-2008): \\
tion of traffic in & - safety means for pedestrian traffic: \\
central part of & - construction of pavement; \\
Ignalina City (I & - reconstruction of car parking place. \\
stage)/ & - means of traffic reorganization in \\
Ignalina Region & Smèlio, Ateities, Atgimimo st. and \\
Municipality & Laisves sq.: \\
& - traffic limitation in Ateities st., traf- \\
& fic forbid in Laisvejs square; \\
& - reconstruction of Laisvès square - \\
& adjusting for safe pedestrian and \\
& bicyclists traffic; \\
& - connection of Atgimimo st. with \\
& Smélio st. \\
& - reconstruction of Smelios st. and exten- \\
& sion to Atgimimo st.
\end{tabular}

Total works: 3220 sq. m. asphalt pavement, $1.4 \mathrm{~km}$ rain water sewerage, $9850 \mathrm{sq}$. $\mathrm{m}$. paths and $2.1 \mathrm{~km}$ street lighting were installed.

Construction Accomplished works (2004-2007):

of pedestrian - construction of metal viaduct (length

viaduct in Kazlu $\quad$ of main hole $-60 \mathrm{~m}$, total width of

Rūda/ Kazlų

Rūda Munici-

pality

viaduct $-3.0 \mathrm{~m}$; height over railway $6.9 \mathrm{~m})$;

- building of ramps for people with disabilities;

- installation of lightening of viaduct;

- creation of 32 new working places.

Reconstruc- Accomplished works (2005-2007):

tion of streets in - reconstruction of $2.4 \mathrm{~km}$ streets

Darbininkų quar- (Darbininkų, Pylimo, Gegužès, Ventès,

ter of Šilute City/ Dirvų, E.Kanto st.):

Šilute Region

Municipality

- construction of asphalt pavement;

- installation of rain water sewage;

- installation of lightening of streets;

- construction of pedestrian paths.

Creation of net- Accomplished works (2005-2007):

work of rounda- Reconstruction of S. Dariaus ir S. Gireno

bout streets in streets $(0.838 \mathrm{~km})$ :

the central part - broadening and amplification of pave-

of Klaipeda City/ ments;

Klaipeda City - construction of pedestrian paths;

Municipality - building of low beads for people with

disabilities at crossing places.

- reconstruction and construction of car parking places;

- installation of traffic-light at crossing of

J. Janonio ir Sportininkų streets;

- installation of rain water sewage;

- reconstruction of street lightening;

- building of noise block boarder.

Reconstruc-

Planned works (2008-2010):

tion of streets Reconstruction of $0.66 \mathrm{~km}$ streets:

(S. Dariaus ir construction of asphalt pavement

S. Girèno st., $\quad$ (3474 sq. m.);

J. Basanavičiaus - building of pedestrian paths

st.) of Birštonas (8899 sq. m.);

City / Birštonas _ - installation of street lightening

City Municipality $\quad(1.425 \mathrm{~km})$;

- planting of greenery in streets area. 


\begin{tabular}{|c|c|}
\hline $\begin{array}{c}\text { Title of project/ } \\
\text { Customer }\end{array}$ & Results of project \\
\hline $\begin{array}{l}\text { Construction of } \\
\text { Marvele street } \\
\text { in Kaunas City/ } \\
\text { Kaunas City } \\
\text { Municipality }\end{array}$ & $\begin{array}{l}\text { Accomplished works (2005-2007 ): } \\
\text { - building of } 2.22 \mathrm{~km} \text { streets with } 4 \\
\text { traffic lanes; } \\
\text { - building of } 2 \text { one level crossings; } \\
\text { - construction of } 21 \text { tunnel-viaducts } \\
\text { for pedestrian: } \\
\text { - construction of pedestrian paths } \\
\quad \text { ( } 10100 \text { sq. m.); } \\
\text { - installation of traffic safety means: } \\
\text { - single-sided boxes }(2.42 \mathrm{~km}) ; \\
\text { - safety barriers }(0.28 \mathrm{~km}) ; \\
\text { - safety islands ( } 4 \text { ps. })\end{array}$ \\
\hline $\begin{array}{l}\text { Reconstruction } \\
\text { of streets and } \\
\text { roads in Rietavas } \\
\text { region (II stage)/ } \\
\text { Rietavas Munici- } \\
\text { pality }\end{array}$ & $\begin{array}{l}\text { Accomplished works (2006-2007): } \\
\text { Reconstruction of } 11,384 \mathrm{~km} \text { streets and } \\
\text { roads: } \\
\text { - construction of asphalt pavement } \\
\quad \text { (52097 sq. m.); } \\
\text { - installation of rain water sewage } \\
\quad(1.584 \mathrm{~km}) ; \\
\text { - installation of street lightening } \\
\quad(1.584 \mathrm{~km}) ; \\
\text { - installation of traffic safety means } \\
\quad(11.384 \mathrm{~km}) ; \\
\text { - building of roadsides (11.384 km); } \\
\text { - creation of } 62 \text { workplaces. }\end{array}$ \\
\hline $\begin{array}{l}\text { Reconstruction } \\
\text { of local streets } \\
\text { and roads of } \\
\text { Radviliškis } \\
\text { City and region } \\
\text { (streets in } \\
\text { Prastavonių, } \\
\text { Mènaičių } \\
\text { villages, road } \\
\text { Ilguočiai- } \\
\text { Miežaičiai)/ } \\
\text { Radviliškis } \\
\text { Region Munici- } \\
\text { pality }\end{array}$ & $\begin{array}{l}\text { Accomplished works }(2006-2008) \text { : } \\
\text { Reconstruction of } 9.72 \mathrm{~km} \text { streets and } \\
\text { roads: } \\
\text { - construction of asphalt pavement } \\
\quad(43678 \mathrm{sq} . \mathrm{m} .) \text {; } \\
\text { - installation of rain water sewage } \\
\quad(9.72 \mathrm{~km}) ; \\
\text { - installation of street lightening } \\
\quad(0.38 \mathrm{~km}) .\end{array}$ \\
\hline
\end{tabular}

ments on the execution of construction works to the costs of construction technical supervision and auditing. The costs of land acquisition and taking off land for public needs also belong to the first group of impacts.

The construction (also repair or reconstruction) costs of the project include the costs of preparing a construction site, the main construction works, customer's reserve for contingencies (with their justification) and the value added tax.

The maintenance costs of the project include the costs of routine maintenance, periodic (or capital) repairs, project monitoring or the costs of implementing later construction stages. The costs during construction works are possibly caused by extended travel time, increased vehicle operating costs, increased ecological costs and additional accident losses.

Several methods were used to calculate project costs: estimates were made with the use of large-scale indices or prices were calculated according to analogical projects taking into consideration the inflation of the corresponding year.
Since projects on urban (also road) transport system infrastructure bring no direct income or income is very low, they give socio-economic benefit to society. Systemizing the results of the carried out analysis, the main social effects used as common evaluation criteria were defined. The structure of these social effects is shown in Table 5.

The analysis of the project evaluation methods used both in foreign countries and in Lithuania showed that there were a number of social costs, especially those related to traffic congestions, which affect an increase in travel time and fuel costs and are potential sources of noise and air pollution. This shows that there is a strong correlation between the costs of road users (time delays and the use of vehicles) and the costs of impacts on the third parties (noise, air or water pollution, vibration, etc.) In other words, savings in the maintenance costs of the objects of new or reconstructed infrastructure, shortened travel time, a reduced number of accidents and lower ecological losses are mainly dependent on better condition and parameters of the object, the length of the route selected, speed limit, traffic volume, etc. After project implementation, better conditions created for society show the benefit of the project.

The analysis of the projects selected showed that there were certain difficulties in defining the impact of transport on the environment. Investment projects should analyze and measure the existing and predicted indices of air pollution, noise, greenhouse effect, however, the calculation of these social costs have been started quite recently (Caulfield and Mahony 2007; Odgaard et al. 2005; Pearce et al. 2006). In the analyzed projects, only the costs of dustiness have been determined due to a rather simple calculation system (Automobilių kelių investicijų vadovas 2006) and a more detailed ecological evaluation of the projects more frequently has a descriptive character or remind us of using multi-criteria evaluation methods (mostly - of expert judgement) the main reason for which could be the imperfection of methods for evaluating the results of environmental impact.

For a comparison of the results of an economic analysis of the projects selected, first of all, the initial data on benefit and costs, the duration of construction (repair or reconstruction) works of the objects, the lifetime of the projects and the used forecasts and discount rate were compared. Table 4 shows that the duration of construction (reconstruction) works of the objects differs and lasts for 24-36 months on the average. The lifetime of the projects depends on the type of works to be implemented (new construction, repair, reconstruction, etc.) and in those cases, based on the EU recommendations, a period of 20 years was selected. In economic evaluation, the forecasts of traffic volume, speed, accidents and pavement degradation (IRI) were mostly used. A social discount rate is of a recommended character and was used as $5 \%$ by a realistic scenario (Automobilių kelių investicijų vadovas 2006; National General Strategy: the Lithuanian ... 2006). Economic evaluation was conducted at the prices of the current year, and therefore the earlier made estimates were re-calculated using 
Table 5. The structure of common social effects used as criteria for the evaluation of the selected projects

\begin{tabular}{|c|c|c|c|}
\hline $\begin{array}{l}\text { Groups of } \\
\text { main social } \\
\text { effects }\end{array}$ & $\begin{array}{l}\text { Results of } \\
\text { project }\end{array}$ & $\begin{array}{l}\text { Measure } \\
\text { Unit }\end{array}$ & Expression \\
\hline \multicolumn{4}{|c|}{ Direct effects to road users } \\
\hline New object & $\begin{array}{l}\text { Reconstructed } \\
\text { or } \\
\text { constructed } \\
\text { streets/ paths/ } \\
\text { crossings/ } \\
\text { bridges and } \\
\text { etc. }\end{array}$ & $\mathrm{km}$ & $\begin{array}{l}\text { Monetary } \\
\text { value of } \\
\text { construction/ } \\
\text { reconstruction/ } \\
\text { maintenance/ } \\
\text { repair costs }\end{array}$ \\
\hline Traffic safety & $\begin{array}{l}\text { Increased/ } \\
\text { decreased }\end{array}$ & $\begin{array}{l}\text { Traffic } \\
\text { accident } \\
\text { number per } \\
\text { one year }\end{array}$ & $\begin{array}{l}\text { Monetary } \\
\text { value of traffic } \\
\text { safety costs }\end{array}$ \\
\hline Travel time & $\begin{array}{l}\text { Shortened/ } \\
\text { elongated }\end{array}$ & $\begin{array}{l}\text { mil. } \\
\text { automobiles } \\
\text { per hour }\end{array}$ & $\begin{array}{l}\text { Monetary } \\
\text { value of travel } \\
\text { time saving } \\
\text { costs }\end{array}$ \\
\hline $\begin{array}{l}\text { Vehicle } \\
\text { operating } \\
\text { costs }\end{array}$ & $\begin{array}{l}\text { Increased/ } \\
\text { decreased }\end{array}$ & IRI $\mathrm{m} / \mathrm{km}$ & $\begin{array}{l}\text { Monetary } \\
\text { value of VOC } \\
\text { saving }\end{array}$ \\
\hline \multicolumn{4}{|c|}{ Indirect effects to road users } \\
\hline $\begin{array}{l}\text { Traffic jams } \\
\text { in different } \\
\text { parts of } \\
\text { urban } \\
\text { territories }\end{array}$ & $\begin{array}{l}\text { Increased/ } \\
\text { decreased }\end{array}$ & $\begin{array}{l}\text { Traffic } \\
\text { volumes } \\
\text { per peak } \\
\text { hours }\end{array}$ & $\begin{array}{l}\text { Qualitative } \\
\text { description }\end{array}$ \\
\hline $\begin{array}{l}\text { Traffic } \\
\text { conditions } \\
\text { for } \\
\text { pedestrian } \\
\text { and bicyclists }\end{array}$ & Better/worse & $\begin{array}{l}\text { Traffic } \\
\text { volumes/ } \\
\text { km/ } \\
\text { percentage }\end{array}$ & $\begin{array}{l}\text { Qualitative } \\
\text { description }\end{array}$ \\
\hline $\begin{array}{l}\text { Living } \\
\text { quality } \\
\text { of local } \\
\text { residents }\end{array}$ & Better/worse & & $\begin{array}{l}\text { Qualitative } \\
\text { description }\end{array}$ \\
\hline $\begin{array}{l}\text { Development } \\
\text { of public } \\
\text { transport } \\
\text { network }\end{array}$ & Better/worse & $\begin{array}{l}\text { Traffic } \\
\text { volumes/ } \\
\text { km/ } \\
\text { percentage }\end{array}$ & $\begin{array}{l}\text { Qualitative } \\
\text { description }\end{array}$ \\
\hline $\begin{array}{l}\text { Working } \\
\text { places }\end{array}$ & $\begin{array}{l}\text { Created/kept/ } \\
\text { permanent/ } \\
\text { temporary }\end{array}$ & $\begin{array}{l}\text { Quantity/ } \\
\text { percentage }\end{array}$ & $\begin{array}{l}\text { Quantitative } \\
\text { or qualitative } \\
\text { description }\end{array}$ \\
\hline \multicolumn{4}{|c|}{ Effects to environment } \\
\hline Noise & $\begin{array}{l}\text { Increased/ } \\
\text { decreased }\end{array}$ & $\mathrm{dB}(\mathrm{A})$ & $\begin{array}{l}\text { Quantitative } \\
\text { or qualitative } \\
\text { description }\end{array}$ \\
\hline $\begin{array}{l}\text { Air } \\
\text { pollution/ } \\
\text { dust }\end{array}$ & $\begin{array}{l}\text { Increased/ } \\
\text { decreased }\end{array}$ & $\begin{array}{l}\text { MAT of } \\
\text { NOx, SO2, } \\
\mathrm{CO} 2, \mathrm{t}\end{array}$ & $\begin{array}{l}\text { Quantitative } \\
\text { or qualitative } \\
\text { description }\end{array}$ \\
\hline $\begin{array}{l}\text { Water/soil } \\
\text { pollution }\end{array}$ & $\begin{array}{l}\text { Increased/ } \\
\text { decreased }\end{array}$ & $\begin{array}{l}\text { MAC } \\
\text { of NOx, } \\
\text { SO2, CO2, } \\
\text { PM10, } \\
\text { VOC, mg/l }\end{array}$ & $\begin{array}{l}\text { Quantitative } \\
\text { or qualitative } \\
\text { description }\end{array}$ \\
\hline $\begin{array}{l}\text { Landscape/ } \\
\text { biodiversity }\end{array}$ & $\begin{array}{l}\text { Increased/ } \\
\text { decreased }\end{array}$ & $\begin{array}{l}\text { Quantity/ } \\
\text { percentage }\end{array}$ & $\begin{array}{l}\text { Quantitative } \\
\text { or qualitative } \\
\text { description }\end{array}$ \\
\hline
\end{tabular}

changes in the construction price index. Analysis was based on economic prices reflecting a real economic value of goods and services, excluding taxes. Having made a comparison of economic results, it could be stated that the economic indices of the projects are satisfactory. The main economic values at the end of project cycle vary within the following limits: IRR - 10-23\% > 5\%, B/C 1.05-3.3 > 1 which shows a sufficient pay-back of investments. If IRR are lower than 5\%, the EU recommends to essentially change the project or to reject it.

\section{Conclusions}

The analysis of the project evaluation methods used both in Lithuania and foreign countries showed that the methods were not standardized and unified. In such a case, the following reasons can be given:

1. There are differences between project implementation, financial support funds and subsidies given. Each country has its own methodology; therefore, the evaluation of identical factors differs according to the country. Some social cost factors such as time saving, accident number reduction, etc. are common to many developed countries. Other effects are characteristic only of several countries and include environmental, land use, local development impacts etc.

2. One relevant problem concerned with the evaluation of investment projects is frequent difficulty to ascribe monetary values to cost and benefit indicators and those which are not priced in the market. For example, travel time savings and traffic accident reduction are included in the project evaluation of many advanced countries; however, their monetary values vary according to the economy of each country. Developing countries still have no data basis for calculating monetary values even speaking about travel time saving or accident reduction. Besides, since the level of GDP is low, monetary expressions of evaluation criteria also remain low comparing with other costs and incoming benefit of the projects.

3. The analysis of evaluation methods showed that the expression of transport generated a negative impact in terms of money and is a rather complicated problem as social costs are involved in it. Each country has its own methodology, and therefore the evaluation of identical factors differs according to the region. In order to determine the effect of certain factors, complicated and expensive investigations are necessary. Thus, during the evaluation of investment projects, some factors are evaluated either in physical units or based on their description.

4. Lithuania encounters a problem concerning the evaluation of projects on road and urban transport system infrastructure. Theoretically, there must be differences between the methods used for evaluating the infrastructure projects of sep- 
arately road transport (main, national, regional roads and their elements, including bridges, viaducts, crossings, barriers etc.) and urban transport systems (streets, city by-passes, pedestrian pavements, bicycle paths etc.) since road and urban transport systems represent different objects operating under different conditions (territories, users etc.). Lithuanian practice shows that common methods are used in the evaluation process.

5. Evaluating investment projects on Lithuanian transport infrastructure in cooperation with the State, multi-criteria analysis started to be used. However, multi-criteria methods are a new approach referring to a quite complicated mathematical basis and requiring the sight of information. Moreover, when evaluating both road and urban transport system infrastructure projects, some factors do not have mathematical quantitative expressions which can be a reason for increasing risk for a wrong interpretation of factors and an uncertain evaluation of projects. Therefore, the legal methodology of evaluating separate investment projects still refers to the classical methods of complex analysis.

6. Costs-benefit analysis is broadly used to evaluate transport investment projects and programmes. The whole benefit of the project or programme rendered to publicity is compared with completed implementation costs. CBA is applied for evaluating the infrastructure of at least one transport mode, often in road or railway sectors, both in Lithuania and the EU countries. CBA is used with both quantitative and (or) qualitative evaluation including criteria not included by former stages due to technical or political reasons.

7. The analysis of the social costs of investment projects on Lithuanian urban transport systems prepared for the EU financial support of I programming period (2004-2006) showed that there were a number of social costs, especially those related to traffic congestions that affected an increase in travel time and fuel costs and were potential sources of noise and air pollution. This shows that there is a strong correlation between the costs of road users (time delays and the use of vehicles) and the costs of impacts on the third parties (noise, air or water pollution, vibration, etc.)

8. The indicators of the economic analysis of the projects selected are middle good which shows the sufficient recoupment of the projects. Several methods were used to calculate project costs: estimates were made using large-scale indices and prices were calculated according to analogical projects taking into consideration the inflation of the corresponding year. Having implemented the projects, better conditions created for society show the benefit of the project.

9. The analysis of the projects selected showed that there were certain difficulties in defining the impact of transport on the environment. In the ana- lyzed projects, only the costs of dustiness have been determined due to a rather simple calculation system and a more detailed ecological evaluation of the projects more frequently has a descriptive character or reminds us of using multicriteria evaluation methods (mostly - of expert judgement) the main reason of which could be the imperfection of methods for evaluating the results of environmental impact.

10. Considering the accomplished analysis of the evaluation methods used both in Lithuania and foreign countries, the analysis of the social costs of Lithuanian investment projects and cost-benefit analysis proves to be most suitable for the economic evaluation of investment projects. It is suggested to pay closer attention to environmental aspects creating new or borrowing the already existing methods calculating negative impacts generated by transport.

\section{Reference}

Antov, D.; Abel, K.; Sürje, P.; Rõuk, H.; Rõivas, T. 2009. Speed reduction effects of urban roundabouts, The Baltic Journal of Road and Bridge Engineering 4(1): 22-26. doi:10.3846/1822-427X.2009.4.22-26

Automobiliu keliu investiciju vadovas [Guide to automobile road investment]. 2006. Lithunian Road Administration under the Ministry of Transport and Communications. KIV-06-1. 85 p. (in Lithuanian).

Bekefi, Z.; Kiss, L. N.; Tanczos, K. 2003. Multicriteria analysis of the financial feasibility of transport infrastructure projects in Hungary, INFOR: Information Systems and Operational Research 41(1): 105-126.

Bello-Dambatta, A.; Farmani, R.; Javadi, A. A.; Evans, B. M. 2009. The analytical hierarchy process for contaminated land management, Advanced Engineering Informatics 23(4): 433-441. doi:10.1016/j.aei.2009.06.006

Bhagwat, R.; Sharma, M. K. 2009. An application of the integrated AHP-PGP model for performance measurement of supply chain management, Production Planning \& Control 20(8): 678-690. doi:10.1080/09537280903069897

Bivainis, J.; Butkevičius, A. 2003. Methodologic aspects of evaluation of state budget programmes, Journal of Business Economics and Management 4(1): 53-61.

Brans, J. P.; Vincke, P. 1985. A preference ranking organization method - (The PROMETHEE method for multiple criteria decision-making), Management Science 31(6): 647-656. doi:10.1287/mnsc.31.6.647

Brauers, W. K. M.; Zavadskas, E. K.; Peldschus, F.; Turskis, Z. 2008. Multi-objective decision-making for road design, Transport 23(3): 183-193. doi:10.3846/1648-4142.2008.23.183-193

Bruinsma, F.; Koetse, M.; Rietveld, P.; Vreeker R. 2001. Social Costs of Land Use Claim for Transport Infrastructure: a Survey for the Netherlands. 25 p. Available from Internet: $<\mathrm{ftp}: / /$ zappa.ubvu.vu.nl/20010033.pdf>.

Bulkeley, H.; Rayner, T. 2003. New realism and local realities: local transport planning in leicester and cambridgeshire, Urban Studies 40(1): 35-55. doi:10.1080/00420980220080151

Burinskienė, M.; Rudzkiene, V. 2009. Future insights, scenarios and expert method application in sustainable territorial planning, Technological and Economic Development of Economy 15(1): 10-25. doi:10.3846/1392-8619.2009.15.10-25 
Burinskienė, M. 2009. New methodology for sustainable development towards sustainable transportation system, Technological and Economic Development of Economy 15(1): 5-9. doi:10.3846/1392-8619.2009.15.5-9

Burinskienė, M.; Rudzkienė, V. 2006. Assessment of strategic innovation, knowledge economy for sustainable development of regions, in WMSCI 2006: 10th World Multi-Conference on Systemics, Cybernetics and Informatics, Vol VII, Proceedings, 139-144.

Burinskienė, M.; Ušpalytė-Vitkūnienè, R. 2008. Integration of public transport and urban planning, in 7 th International Conference Environmental Engineering, Vols 1-3, 1075-1080.

Cantos, P.; Gumbau-Albert, M.; Maudos, J. 2005. Transport infrastructures, spillover effects and regional growth: evidence of the Spanish case, Transport Reviews 25(1): 25-50. doi:10.1080/014416410001676852

Caulfield, B.; O'Mahony, M. 2007. Evaluating the economic cost of air and noise pollution generated by transport, in European Transport Conference 2007, Leeuwenhorst Conference Centre, The Netherlands 17-19 October 2007, 16 p. Available from Internet: <www.etcproceedings.org/paper/ download/3202>.

Communication from the Commission to the European Parliament and the Council - Greening Transport $\{$ SEC(2008) 2206\} / COM/2008/0433 final/. 2008. European Commission. Available from Internet: <http://eur-lex.europa.eu/LexUriServ/ LexUriServ.do?uri=COM:2008:0433:FIN:EN:HTML >.

Çalışkanelli, P.; Özuysal, M.; Tanyel, S.; Yayla, N. 2009. Comparison of different capacity models for traffic circles, Transport 24(4): 257-264. doi:10.3846/1648-4142.2009.24.257-264

Daunoras, J.; Bagdonas, V.; Gargasas, V. 2008. City transport monitoring and routes optimal management system, Transport 23(2): 144-149. doi:10.3846/1648-4142.2008.23.144-149

Eliasson, J. 2006. Cost-benefit analysis of the Stockholm congestion charging system, in European Transport Conference 2006, Strasbourg, France, 18-20 September 2006, 18 p. Available from Internet: <http://siteresources.worldbank.org/INTTRANSPORT/Resources/StockholmcongestionCBAEliassonn.pdf $>$.

Feng, C.-M.; Wang, S.-M. 2005. The fully economic evaluation for transport infrastructure project, in Proceedings of the Eastern Asia Society for Transportation Studies, 5: 17781791. Available from Internet: <http://www.easts.info/online/proceedings_05/1778.pdf $>$.

Figliozzi, M. A. 2008. Planning approximations to the average length of vehicle routing problems with varying customer demands and routing constraints, Transportation Research Record: Journal of the Transportation Research Board 2089: 1-8. doi:10.3141/2089-01

Ghionea, F. 2009. About the electre method applicabillity, Metalurgia International 14(Sp. Iss. 16): 16-23.

Golub, S. S.; Tomasik, B. 2008. Measures of international transport cost for OECD countries, OECD Economic Department Working Papers No. 609, ECO/WKP(2008)17. 30 p. doi:10.1787/18151973

Griškevičius, A.; Griškevičienè, D. 2004. The efficiency of investments into the projects of transport infrastructure development, in Transport Means 2004: Proceedings of the International Conference, 221-224.

Griškevičius, A.; Griškevičienè, D. 2007. The opportunities of comprehensive evaluation and financing of transport business projects, in Transport Means 2007, Proceedings, 175-178.
Guide to Cost-Benefit Analysis of Investment Projects: Structural Funds, Cohesion Fund and Instrument for Pre-Accession. 2008. European Commission. Directorate General Regional Policy. Final Report Submitted by TRT Trasporti e Territorio and CSIL Centre for Industrial Studies 16/06/2008. 255 p. Available from Internet: <http://sk-at.eu/sk-at/ downloads/EN/CBAguide2008_en.pdf>.

Guy, G. B.; Kibert, C. J. 1998. Developing Indicators of Sustainability: US Experience, Building Research and Information 26(1): 39-45. doi:10.1080/096132198370092

Herala, N. 2003. Regulating traffic with land use planning, Sustainable Development 11(2): 91-102. doi:10.1002/sd.209

Janáček, J.; Gábrišová, L. 2009. A two-phase method for the capacitated facility problem of compact customer sub-sets, Transport 24(4): 274-282.

doi:10.3846/1648-4142.2009.24.274-282

Juškevičius, P.; Burinskienè, M. 2007. Quality factors of the residential environment in urban planning, International Journal of Environment and Pollution 30(3/4): 471-484 . doi:10.1504/IJEP.2007.014823

Kinderytė-Poškienė, J.; Sokolovskij, E. 2008. Traffic control elements influence on accidents, mobility and the environment, Transport 23(1): 55-58. doi:10.3846/1648-4142.2008.23.55-58

Kulkarni, R. B.; Miller, D.; Ingram, R. M.; Wong, C.-W.; Lorenz, J. 2004. Need-based project prioritization: Alternative to cost-benefit analysis, Journal of Transportation Engineering - ASCE 130(2): 150-158. doi:10.1061/(ASCE)0733-947X(2004)130:2(150)

Li, Sh.; Deng, W.; Lv, Y. 2009. Combined modal split and assignment model for the multimodal transportation network of the economic circle in China, Transport 24(3): 241-248. doi:10.3846/1648-4142.2009.24.241-248

Lithuanian Road Adminsitration under the Minsitry of Transport and Communications. 2002. Lithuanian Highway Project. Kaunas: VI „Transporto ir kelių tyrimo instituta““. $145 \mathrm{p}$.

Macharis, C. ; De Witte, A. ; Ampe, J. 2009. The multi-actor multi-criteria analysis methodology for the evaluation of transport projects: Theory and practice, Journal of Advanced Transportation 43(2): 183-202. doi:10.1002/atr.5670430206

Matis, P. 2010. Finding a solution for a complex street routing problem using the mixed transportation mode, Transport 25(1): 29-35. doi:10.3846/transport.2010.05

Matis, P. 2008. Decision support system for solving the street routing problem, Transport 23(3): 230-235. doi:10.3846/1648-4142.2008.23.230-235

McDonald, S.; Malys, N.; Malienė, V. 2009. Urban regeneration for sustainable communities: a case study, Technological and Economic Development of Economy 15(1): 49-59. doi:10.3846/1392-8619.2009.15.49-59

Mesarec, B.; Lep, M. 2009. Combining the grid-based spatial planning and network-based transport planning, Technological and Economic Development of Economy 15(1): 6077. doi:10.3846/1392-8619.2009.15.60-77

Moss, T.; Fichter, H. 2003. Lessons in promoting sustainable development in EU structural funds programmes, Sustainable Development 11(1): 56-65. doi:10.1002/sd.204

National General Strategy: the Lithuanian Strategy for the Use of European Union Structural Assistance for 2007-2013. 2006. Available from Internet: <www.esparama.lt/ES_Parama/angliskas_medis/programming_for_2007_2013_tree/ front_page/files/NSRF_1.doc $>$. 
Niewczas, A.; Koszalka, G.; Wrona, J.; Pieniak, D. 2008. Chosen aspects of municipal transport operation on the example of the city of Lublin, Transport 23(1): 88-90. doi:10.3846/1648-4142.2008.23.88-90

Noya, A.; Clarence, E. 2007. The Social Economy: Building Inclusive Economies. OECD Publishing. 250 p.

Nystrom, B.; Soderholm, P. 2010. Selection of maintenance actions using the analytic hierarchy process (AHP): decisionmaking in railway infrastructure, Structure and Infrastructure Engineering 6(4): 467-479. doi:10.1080/15732470801990209

Odgaard, T.; Kelly, C. E.; Laird, J. J. 2005. Current practice in project appraisal in Europe, in European Transport Conference 2002, Strasbourg, France, 3-5 October 2005. 23 p. Available from Internet: <www.etcproceedings.org/paper/ download $/ 50>$.

Ojha, A.; Das, B.; Mondal, S.; Maiti, M. 2010. A stochastic discounted multi-objective solid transportation problem for breakable items using analytical hierarchy process, Applied Mathematical Modelling 34(8): 2256-2271. doi:10.1016/j.apm.2009.10.034

Oppen, J.; Løkketangen, A. 2006. Arc routing in a node routing environment, Computers \& Operations Research 33(4): 1033-1055. doi:10.1016/j.cor.2004.09.004

Pearce, D.; Atkinson, G.; Mourato, S. 2006. Cost-Benefit Analysis and the Environment: Recent Developments. OECD Publishing, 1st edition. 316 p.

Planuojamos ūkines veiklos poveikio aplinkai vertinimo vadovas [Guide on the Environmental Impact Assessment of Planned Economic Activities]. 2009. Lietuvos Respublikos Aplinkos ministerija [The Ministry of Environment of the Republic of Lithuania]. 108 p. Available from Internet: <www.am.lt/VI/files/0.519685001249378224.pdf>. (in Lithuanian).

Podvezko, V. 2009. Application of AHP technique, Journal of Business Economics and Management 10(2): 181-189. doi:10.3846/1611-1699.2009.10.181-189

Podvezko, V.; Podviezko, A. 2010. Dependence of multi-criteria evaluation result on choice of preference functions and their parameters, Technological and Economic Development of Economy 16(1): 143-158. doi:10.3846/tede.2010.09

Podvezko, V.; Podviezko, A. 2009. PROMETHEE I Method Application for Identification of the Best Alternative, Verslas: teorija ir praktika [Business: Theory and Practice] 10(2): 84-92. doi:10.3846/1648-0627.2009.10.84-92

Poot, A.; Kant, G.; Wagelmans, A. P. M. 2002. A Saving based method for real- life vehicle routing problems, Journal of the Operational Research Society 53(1): 57-68.

doi:10.1057/palgrave/jors/2601252

Rich, J. H., Nielsen, O. A. 2002. Cost-benefit Evaluation of infrastructure doing it the hedonic way, in European Transport Conference 2002, Homerton College, Cambridge, 0911 September 2002, 15 p. Available from Internet: <www. etcproceedings.org/paper/download/576>.

Ruiz, R.; Maroto, C. ; Alcaraz, J. 2004. A decision support system for a real vehicle routing problem, European Journal of Operational Research 153(3): 593-606. doi:10.1016/S0377-2217(03)00265-0

Rus, G. 2006. Economic evaluation and incentives in transport infrastructure investment. OECD, Milan European Economy Workshops Working paper No. 2006-25. 29 p. Available from Intrenet: <www.economia.unimi.it/uploads/wp/DE_ RUS-2006_25.pdf>.
Szűcs, G. 2009. Developing co-operative transport system and route planning, Transport 24(1): 21-25. doi:10.3846/1648-4142.2009.24.21-25

Single Programming Document of Lithuania 2004-2006. 2004. Available from Internet: <http://www.transp.lt/files/uploads/client/Lithuanian_SPD_03.12._FINAL.doc>.

Šarka, V.; Zavadskas, E. K.; Ustinovičius, L.; Šarkienè, E.; Ignatavičius, Č. 2008. System of project multicriteria decision synthesis in construction, Technological and Economic Development of Economy 14(4): 546-565. doi:10.3846/1392-8619.2008.14.546-565

Tamošiūnienė, R.; Šidlauskas, S.; Trumpaite, I. 2006. The multicriterial evaluation method of the effectiveness of the investment projects, Verslas: teorija ir praktika [Business: Theory and Practice] 7(4): 203-212.

Tanczos, K.; Torok, A. 2007. Linear optimization model of urban areas' operating efficiency, Transport 22(3): 225-228.

Ulubeyli, S.; Kazaz, A. 2009. A multiple criteria decisionmaking approach to the selection of concrete pumps, Journal of Civil Engineering and Management 15(4): 369-376. doi:10.3846/1392-3730.2009.15.369-376

Vega, H. L. ; Penne, L. 2008. Governance and institutions of transportation investments in U.S. mega-regions, Transport 23(3): 279-286. doi:10.3846/1648-4142.2008.23.279-286

Yuen, B.; Chor, C. H. 1998. Pedestrian streets in Singapore, Transportation 25(3): 225-242. doi:10.1023/A:1005055225542

Ziari, H.; Keymanesh, M. R.; Khabiri, M. M. 2007. Locating stations of public transportation vehicles for improving transit accessibility, Transport 22(2): 99-104. 